\title{
30-Е ЗАСЕДАНИЕ РУССКОГО ИНТЕЛЛЕКТУАЛЬНОГО КЛУБА НА ТЕМУ «30 ЛЕТ “ПЕРЕСТРОЙКИ”: ОЖИДАНИЯ И ПОСЛЕДСТВИЯ»
}

\author{
С. В. Луков \\ (Московский гуманитарный университет)
}

\begin{abstract}
Аннотация: В статье представлен обзор 30-го заседания Русского интеллектуального клуба, который состоялся 25 ноября 2015 г. в Московском гуманитарном университете. Дискуссия была посвящена периоду истории России 1985-1990 г2. - «перестройке».
\end{abstract}

Ключевые слова: Русский интеллектуальный клуб; Московский гуманитарный университет; обзор; перестройка

$30^{\mathrm{TH}}$ SESSION OF THE RUSSIAN INTELLECTUAL CLUB: $30^{\text {TH }}$ ANNIVERSARY OF THE PERESTROIKA: EXPECTATIONS AND AFTERMATH

\author{
S. V. Lukov \\ (Moscow University for the Humanities)
}

Abstract: The article overviews the 30th session of the Russian Intellectual Club, which took place on November 25, 2015 at Moscow University for the Humanities. The session was devoted to the Perestroika as a period in the history of Russia (1985-1990).

Keywords: Russian Intellectual Club; Moscow University for the Humanities; overview; Perestroika

25 ноября 2015 г. в Московском гуманитарном университете состоялось 30-е заседание Русского интеллектуального клуба. Заседание было посвящено теме «30 лет “перестройки”: ожидания и последствия».

Со вступительным словом к участникам обсуждения обратился президент Русского интеллектуального клуба, ректор Московского гуманитарного университета, доктор философских наук, профессор Игорь Михайлович Ильинский. Он, в частности, подчеркнул, что час для однозначных оценок и выводов «перестройки» еще не настал: «Однако я, как человек, живший в ту эпоху, которую называют “сталинизмом”, “волюнтаризмом и субъективизмом”, “застоем” и “перестройкой” и не презревший ни один из этих этапов ни по отдельности, ни вместе взятые, считаю и убежден, что, по крайней мере, люди моего поколения и моих лет жиз- 
ни должны, пока способны, изучать наше прошлое как цельный отрезок истории своего отечества без чувства мести, ненависти и презрения (даже если у кого-то для этого есть личные основания), а именно объективно на основе достоверных фактов, взвешенных рассуждений и трезвых выводов, обязаны и должны делать это. Для меня в равной мере неприемлемы как ультралибералы, так и ультраортодоксы и ура-патриоты». Полный текст его доклада опубликован в журнале «Знание. Понимание. Умение» (Ильинский, 2015).

Для обсуждения на заседании Русского интеллектуального клуба были предложены следующие вопросы:

• «перестройка» - выражение народного ожидания перемен?;

• «перестройка» как замысел «верхов» относительно коренных перемен в советском обществе;

• формула 1985 года «гласность - ускорение - перестройка»: что удалось и чего не удалось достичь?;

• роль личности в «перестройке»;

• раскол в общественном сознании: культурный шок от «перестройки»;

- место «перестройки» в истории России;

- «перестройка» в историческом сознании молодежи.

С основными докладами выступили член Русского интеллектуального клуба экономист и публицист Юрий Юрьевич Болдырев, который избирался депутатом Первого Съезда народных депутатов СССР (1989-1992 гг.), делегатом XVIII съезда КПСС (1990 г.), и президент Ассоциации юридических вузов, доктор юридических наук, заслуженный деятель науки Российской Федерации Сергей Николаевич Бабурин, который избирался депутатом Государственной думы I, II и IV созывов, был заместителем председателя Государственной думы II и IV созывов, членом Комитета ГД по гражданскому, уголовному, арбитражному и процессуальному законодательству. В 1990-1993 гг. С. Н. Бабурин был народным депутатом РСФСР, членом Совета Республики Верховного Совета РСФСР.

После докладов развернулась оживленная дискуссия, в которой выступили члены Русского интеллектуального клуба:

А. А. Лиханов, писатель, председатель Правления Российского детского фонда, президент Международной ассоциации детских фондов, академик РАО, академик РАЕН, лауреат Бунинской премии;

В. М. Межуев, главный научный сотрудник Института философии РАН, доктор философских наук, профессор;

К. К. Колин, главный научный сотрудник Института проблем информатики Федерального исследовательского центра «Информатика и управление» РАН, вице-президент Аналитического центра стратегических исследований «СОКОЛ», заслуженный деятель науки РФ, доктор тех- 
нических наук, профессор;

П. Ф. Алёшкин, главный редактор журнала «Наша молодежь», член правления и секретарь правления Союза писателей России, член Президиума Литературного фонда России, генеральный директор издательства «Голос-Пресс», доктор исторических наук;

И. С. Даниленко, профессор Военной академии Генерального штаба ВС РФ, доктор философских наук, профессор, генерал-майор в отставке.

В дискуссии также участвовали приглашенные эксперты - ведущий научный сотрудник Института философии РАН, доктор философских наук А. А. Горелов, профессор Государственного университета управления, доктор политических наук В. А. Волох, профессор кафедры теории и истории государства и права Московского государственного университета технологий и управления им. К. Г. Разумовского, доктор исторических наук, профессор А. Ф. Хутин, руководитель Центра по изучению проблем информатики Институтанаучнойинформации по общественным наукам РАН, кандидат философских наук Ю. Ю. Черный, начальник Отдела геополитической информации Аналитического центра стратегических исследований «СОКОЛ», кандидат военных наук М. П. Шабалов, профессор кафедры политологии и социальной политики Российского государственного социального университета, доктор философских наук, профессор Г. И. Авцинова, профессора Московского гуманитарного университета В. И. Буренко, О. И. Карпухин, А. И. Ковалева, Н. Н. Платошкин и др.

В конце заседания И. М. Ильинский подвел итоги обсуждения.

\section{СПИСОК ЛИТЕРАТУРЫ}

Ильинский, И. М. (2015) История: стихия и заговор // Знание. Понимание. Умение. № 4. С. 5-14. DOI: 10.17805/zpu.2015.4.1

Луков Сергей Валерьевич - кандидат социологических наук, заместительдиректора Центра социологии молодежи Института фундаментальных и прикладных исследований Московского гуманитарного университета. Адрес: 111395, Россия, г. Москва, ул. Юности, д. 5, корп. 6.Тел.: +7 (499) 374-75-95. Эл. адрес: sv-lukov@rambler.ru

Lukov Sergei Valerievich, Candidate of Sociology, Deputy Director, Center for Sociology of Youth, Institute of Fundamental and Applied Studies, Moscow University for the Humanities. Postal address: 5 Yunosti St., 111395 Moscow, Russian Federation. Tel.: +7 (499) 374-75-95. E-mail: sv-lukov@rambler.ru 